\title{
Genetic Variability, Heritability and Genetic Advance Studies for Different Characters of Tomato (Solanum lycopersicum L.)
}

\author{
Shreya Rini Titus*, Anita Kerketta and Vijay Bahadur \\ Department of Horticulture, Naini Agricultural Institute, SHUATS, \\ Prayagraj Allahabad, U.P., India \\ *Corresponding author
}

\section{A B S T R A C T}

\section{Keywords}

Genetic variability,

Heritability,

Genetic advance

and Tomato

Article Info

Accepted:

12 November 2020

Available Online:

10 December 2020
The genetic materials was consisted of twenty one tomato hybrids. Trial shown in a randomized block design (RBD) with three replications was used. Experiment was conducted at Farm of Dept of Horticulture at Naini Agricultural Institute, Sam Higginbottom University of Agriculture, Technology and Sciences Naini, Prayagraj Uttar Pradesh in Rabi season 2019.Mean square due to treatments revealed that significant differences among the hybrids for all the traits except number of fruit set per cluster, fruit weight, number of locules per fruit, number of locules per fruit, fruit shape index and total soluble solid. High GCV and PCV were exhibited for number of fruit yield per plant and leaf curl incidence. High estimate of heritability were exhibited for leaf curl incidence, number of fruit yield per plant, plant height and days to $50 \%$ flowering. The genetic advance as percentage of mean was highest for number of fruit yield per plant and leaf curl incidence recorded.So that it is concluded that the characters which showed high GCV, PCV and heritability coupled with genetic advance should be considered for direct selection. Here fruit yield per plant and leaf curl incidence the character under study showed high heritability and genetic advance. Thus one should select these characters for direct selection.

\section{Introduction}

Tomato (Solanum lycopersicum $\mathrm{L}$., $2 \mathrm{n}=2 \mathrm{x}=$ $24)$ is one of the widely grown vegetable crops cultivated for its fleshy fruits in the world. It belongs to the Solanaceae family with other frugally important crops such as pepper, eggplant and potato. Tomato is a rich source of vitamins (A and $\mathrm{C}$ ), minerals $(\mathrm{Ca}, \mathrm{P}$ and $\mathrm{Fe}$ ) and a strong antioxidant against cancer and heart diseases (Dhaliwal et al., 2003). Tomato is protective supplementary food and considered as important commercial and dietary vegetable crop. It is also a good source of polyphenolic compounds, such as flavonoids and hydroxyl cinnamic acids (Bugianesi et al., 2004). It is known as an important source of vitamins and minerals due to adequate vitamins $\mathrm{A}$ and $\mathrm{C}$, calcium and iron.

Tomato's fruit is consumed in providing salads and cookies. In addition, it is used to can, paste, ketchup, sauce, puree and fruit 
juice (Maitidevi and Kathmandu, 2008).Cultivated tomato covers less than $5 \%$ of the genetic variation of wild relatives (Ghosh et al., 2010). Due to resilient genetic barriers (self-incompatibility, unilateral incompatibility, embryo rescue etc.) between cultivated and wild species of Solanum (Tigchelaar, 1986), the efforts to combine novel genes particularly those owing biotic and abiotic stresses and extended shelf life have met partial success.

According to Falconer and Mackay (1996), heritability is defined as the measure of the correspondence between breeding values and phenotypic values. Thus, heritability plays a predictive role in breeding, expressing the reliability of phenotype as a guide to its breeding value. It is the breeding value which determines how much of the phenotype would be passed onto the next generation (Tazeen $e t$ al., 2009).

There is a direct relationship between heritability and response to selection, which is referred to as genetic advance. High genetic advance with high heritability estimates offer the most effective condition for selection (Larik et al., 2000). The utility of heritability therefore increases when it is used to calculate genetic advance, which indicates the degree of gain in a character obtained under a particular selection pressure. Thus, genetic advance is yet another important selection parameter that aids breeder in a selection programme.

Knowledge of the extent and pattern of variability, heritability of the trait and genetic gain. The core objective of the present study was therefore, to estimate the extent of genetic variability, yield and yield contributing traits on different hybrids and to set up a selection criterion for the isolation of promising hybrids to develop commercial cultivars.

\section{Materials and Methods}

\section{Location and source of experiment}

The experiment was conducted at Farm of Dept of Horticulture at Naini Agricultural Institute, Sam Higginbottom University of Agriculture, Technology and Sciences Naini, Prayagraj, Uttar Pradesh in Rabi season 2019.The genetic materials was consisted of twenty one tomato hybrids. The experiment was laid out in Randomized Complete Block design (RCBD) with three replications. An inter-row spacing of $60 \mathrm{~cm}$ and inter-plant distance of $45 \mathrm{~cm}$ was maintained. All the recommended package of practices was followed to get a healthy crop. The hybrids was taken from SHUATS, Naini, Department of Horticulture.

\section{Observations}

The data on fruit yield and its components were recorded on five randomly plants taken in each hybrids from each replication for fourteen characters viz., plant height, number of flower per cluster, number of flower cluster per plant, number of fruit set per cluster, fruit weight, number of fruits per plant, number of locules per fruit, fruit shape index, Pericarp thickness, total soluble solid, leaf curl incidence and number of fruit yield per plant. Days to first flowering and days of 50\% flowering were recorded on plot basis. Genotypic coefficient of variation (GCV), phenotypic coefficient of variation (PCV), broad sense heritability and genetic advance in per cent of mean were computed as per standard formulas.The data collected on different parameters during the course of investigation were subjected to statistical analysis as per method of analysis of variance (Panse and Sukhatme, 1957). The significance and non-significance of the treatment effect were judged with the help of ' $F$ ' variance ratio test. Calculated ' $F$ ' value (variance ratio) 
was compared with the table value of ' $F$ ' at $5 \%$ level of significance. If calculated value exceeded the table value, the effect was considered to be significant.

\section{Results and Discussion}

\section{Analysis of Variance}

Analysis of variance revealed that significant differences among the hybrids for all the traits except number of fruit set per cluster, fruit weight, number of locules per fruit, number of locules per fruit, fruit shape index and total soluble solid under study indicating the presence of substantial genetic variability in tomato (Table-1). Similar results proposed Shashikanth et al., (2010), Patel et al., (2013) and Bhandari et al., (2017),

\section{Per se performance of hybrids}

For each of the traits evaluated, the descriptive statistics including the extreme hybrids mean values and the means together with their standard errors obtained on the basis of average data are summarized in Table 1. In general, tomato hybrids showed wide range of variability for most of the characters and all the traits exhibited broad spectrum of ranges between the maximum and minimum hybrids mean values. For instance, days to first flowering ranged from 31.71 to 37.07 with mean of 34.68 , days to $50 \%$ flowering ranged from 42.25 to 48.46 with a mean of 45.73 .

Similarly, plant height and number of flower per cluster ranged from $79.94 \mathrm{~cm}$ to $97.24 \mathrm{~cm}$ and 6.74 to 9.44 , respectively while, number of flower cluster per plant varied from 8.61 to with mean of 11.08. Number of fruit set per cluster ranged from 3.42 to 5.24 with mean of 4.07, for fruit weight ranged varied from 47.83 to 86.76 with mean value of 64.70 and number of fruits per plant ranged varied from
32.82 to 62.14 with average value 44.69. Similarlynumber of locules per fruit ranged varied from 2.49 to 4.34 with mean of 3.38 , fruit shape index from 0.70 to 1.07 with average value of 0.87 and pericarp thickness ranged varied from 3.79 to 4.92 with mean of 4.46.Total soluble solid ranged varied from3.21 to 4.16 with mean of 4.16 and leaf curl incidence also ranged varied from 17.22 to 41.66 with mean value of 28.50.The maximum number of fruit yield per plant obtained was Pant T-7 x KashiAman (4.71) followed by S-22 x KashiAman (4.36), Pant T $x$ H-88-78-5 (4.34) and Azad T-6 x KashiAman (3.53) and it ranged varied from 1.91 to 4.71 with mean of 2.88 . Thus, it is possible to succeed in improving fruit yield by direct selection. Similar results reported by Emami and Eivaz, (2013), Saleem, et al., (2013) and Meena et al., (2015).

\section{Heritability}

In general sense, heritability specifies the proportion of the total variability that is genetic causes, or the ratio of genotypic variance to the total variance. It is a good index of the transmission of characters from parents to their offspring (Falconer, 1960). The reliability of the phenotypic value depends on the estimates of heritability for a particular character. Therefore higher heritability helps in the effective selection for a particular character. In the present investigation heritability in broad sense was calculated for all characters under study and is presented in (Table 2). Heritability is classified as high (above60\%), medium (30\%$60 \%$ ) and low (below 30\%) as suggested by (Johnson et al,. 1955). High estimate of heritability were exhibited for leaf curl incidence (85.50) followed by number of fruit yield per plant (82.40), plant height (79.70) and days to $50 \%$ flowering (73.70) the character under study. 
Table.1 Per se performance of 21 different crosses (Hybrids) for fruit yield and its component traits in tomato

\begin{tabular}{|c|c|c|c|c|c|c|c|c|c|c|c|c|c|c|}
\hline Hybrids & $\begin{array}{c}\text { Plant } \\
\text { Height }\end{array}$ & $\begin{array}{l}\text { Days to first } \\
\text { flowering }\end{array}$ & $\begin{array}{c}\text { Days to } \\
50 \% \\
\text { flowering }\end{array}$ & $\begin{array}{c}\text { Number } \\
\text { of flower } \\
\text { per } \\
\text { cluster }\end{array}$ & $\begin{array}{c}\text { No. of } \\
\text { flower } \\
\text { cluster } \\
\text { per plant }\end{array}$ & $\begin{array}{c}\text { No. of } \\
\text { fruit set } \\
\text { per } \\
\text { cluster }\end{array}$ & $\begin{array}{c}\text { Fruit } \\
\text { weight }\end{array}$ & $\begin{array}{c}\text { No. of } \\
\text { fruits per } \\
\text { plant }\end{array}$ & $\begin{array}{c}\text { No. of } \\
\text { locules } \\
\text { per fruit }\end{array}$ & $\begin{array}{l}\text { Fruit } \\
\text { shape } \\
\text { index }\end{array}$ & $\begin{array}{l}\text { Pericarp } \\
\text { thickness }\end{array}$ & $\begin{array}{c}\text { Total } \\
\text { soluble } \\
\text { solid }\end{array}$ & $\begin{array}{l}\text { Leaf curl } \\
\text { incidence }\end{array}$ & $\begin{array}{c}\text { No. of } \\
\text { fruit } \\
\text { yield per } \\
\text { plant }\end{array}$ \\
\hline ArkaVikashxKashiAman & 79.94 & 33.83 & 44.93 & 8.35 & 12.10 & 3.73 & 56.00 & 45.36 & 2.49 & 0.88 & 4.95 & 3.45 & 17.22 & 2.45 \\
\hline ArkaVikashx KashiVishesh & 81.25 & 36.42 & 47.05 & 6.78 & 12.55 & 3.75 & 67.47 & 46.19 & 2.94 & 0.84 & 4.60 & 3.61 & 18.88 & 3.11 \\
\hline ArkaVikash x H -88-78-5 & 94.36 & 31.79 & 43.64 & 6.79 & 10.83 & 4.24 & 48.00 & 45.37 & 3.50 & 0.85 & 3.79 & 3.65 & 26.66 & 2.24 \\
\hline Pant T-7 x KashiAman & 84.72 & 37.08 & 47.99 & 7.63 & 14.28 & 3.83 & 86.77 & 54.24 & 3.51 & 0.88 & 4.34 & 4.13 & 36.11 & 4.71 \\
\hline Pant T-7 x KashiVishesh & 85.30 & 31.71 & 42.26 & 6.74 & 13.28 & 4.66 & 47.83 & 62.14 & 4.21 & 0.92 & 4.23 & 3.44 & 26.66 & 2.92 \\
\hline Pant T-7 x H -88-78-5 & 88.21 & 35.08 & 44.95 & 7.66 & 13.78 & 4.37 & 72.80 & 60.35 & 3.54 & 0.91 & 4.81 & 3.69 & 33.33 & 4.34 \\
\hline Azad T-6 x KashiAman & 91.30 & 33.78 & 44.91 & 8.12 & 12.33 & 3.92 & 73.73 & 48.52 & 4.34 & 0.85 & 4.61 & 3.66 & 41.66 & 3.53 \\
\hline Azad T-6 x KashiVishesh & 90.63 & 33.85 & 45.54 & 7.79 & 11.17 & 3.42 & 52.33 & 38.15 & 2.92 & 0.99 & 4.25 & 3.64 & 25.55 & 2.07 \\
\hline Azad T-6 x H -88-78-5 & 91.59 & 34.46 & 46.94 & 8.64 & 10.54 & 3.74 & 56.60 & 39.12 & 3.86 & 0.81 & 4.16 & 4.02 & 25.00 & 2.00 \\
\hline S - 22 x KashiAman & 82.04 & 34.45 & 45.23 & 7.54 & 11.13 & 4.38 & 83.90 & 48.13 & 3.11 & 0.88 & 4.21 & 3.54 & 31.66 & 4.36 \\
\hline S - 22 x KashiVishesh & 83.37 & 32.45 & 43.19 & 9.13 & 10.78 & 3.74 & 68.67 & 39.98 & 3.44 & 0.91 & 4.66 & 3.21 & 27.78 & 2.81 \\
\hline S - $22 \times$ H -88-78-5 & 97.24 & 35.78 & 45.76 & 7.92 & 10.21 & 3.57 & 53.30 & 36.46 & 3.62 & 0.79 & 4.67 & 4.16 & 23.33 & 1.91 \\
\hline ArkaAbha x KashiAman & 86.00 & 35.18 & 46.52 & 7.84 & 9.76 & 5.01 & 63.67 & 48.02 & 3.71 & 1.01 & 4.58 & 3.27 & 25.33 & 2.93 \\
\hline ArkaAbha x KashiVishesh & 87.61 & 36.02 & 46.73 & 7.37 & 10.06 & 4.89 & 62.37 & 49.35 & 3.00 & 0.85 & 4.57 & 3.31 & 20.55 & 2.89 \\
\hline ArkaAbha x H -88-78-5 & 87.14 & 35.10 & 46.01 & 9.44 & 9.24 & 3.83 & 63.30 & 35.32 & 3.37 & 0.91 & 4.92 & 3.30 & 30.00 & 2.19 \\
\hline KashiSharad x KashiAman & 85.77 & 36.44 & 47.38 & 7.69 & 11.37 & 3.46 & 80.63 & 39.23 & 3.55 & 0.75 & 4.73 & 3.51 & 36.66 & 3.10 \\
\hline KashiSharad x KashiVishesh & 80.46 & 32.92 & 43.37 & 7.29 & 10.64 & 3.79 & 66.43 & 40.43 & 3.36 & 1.07 & 3.99 & 3.23 & 36.11 & 2.67 \\
\hline KashiSharad x H -88-78-5 & 83.93 & 35.09 & 45.31 & 7.91 & 9.84 & 4.59 & 54.67 & 43.06 & 2.91 & 0.77 & 3.95 & 3.56 & 33.33 & 2.35 \\
\hline HisarLalit x KashiAman & 85.98 & 35.96 & 47.36 & 7.83 & 8.72 & 5.24 & 59.00 & 46.35 & 3.09 & 0.93 & 4.57 & 4.13 & 29.44 & 2.57 \\
\hline HisarLalit x KashiVishesh & 85.25 & 35.00 & 46.82 & 8.05 & 8.61 & 3.81 & 69.43 & 32.82 & 3.42 & 0.82 & 4.54 & 3.21 & 20.00 & 2.30 \\
\hline HisarLalit x H -88-78-5 & 92.24 & 35.94 & 48.46 & 9.17 & 11.44 & 3.48 & 71.90 & 39.87 & 3.09 & 0.71 & 4.46 & 3.56 & 33.33 & 2.94 \\
\hline Mean & 86.87 & 34.68 & 45.73 & 7.89 & 11.08 & 4.07 & 64.70 & 44.69 & 3.38 & 0.87 & 4.46 & 3.58 & 28.50 & 2.88 \\
\hline C.V. & 2.58 & 3.60 & 2.05 & 11.83 & 12.13 & 17.29 & 22.37 & 17.65 & 17.70 & 14.05 & 6.18 & 11.19 & 9.22 & 12.22 \\
\hline S.E. & 1.29 & 0.72 & 0.54 & 0.54 & 0.78 & 0.41 & 8.36 & 4.55 & 0.35 & 0.07 & 0.16 & 0.23 & 1.52 & 0.20 \\
\hline C.D. $5 \%$ & 3.70 & 2.06 & 1.54 & 1.54 & 2.22 & 1.16 & 13.02 & 13.02 & 0.99 & 0.20 & 0.45 & 0.66 & 4.34 & 0.58 \\
\hline C.D. $1 \%$ & 4.95 & 2.76 & 2.07 & 2.06 & 2.97 & 1.55 & 17.42 & 17.42 & 1.32 & 0.27 & 0.61 & 0.89 & 5.80 & 0.78 \\
\hline Min. & 79.94 & 31.71 & 42.26 & 6.74 & 8.61 & 3.42 & 47.83 & 32.82 & 2.49 & 0.71 & 3.79 & 3.21 & 17.22 & 1.91 \\
\hline Max. & 97.24 & 37.08 & 48.46 & 9.44 & 14.28 & 5.24 & 86.77 & 62.14 & 4.34 & 1.07 & 4.92 & 4.16 & 41.66 & 4.71 \\
\hline
\end{tabular}


Table.2 Estimates of variability, heritability and genetic advance as percentage of mean

\begin{tabular}{|c|c|c|c|c|c|c|c|c|c|}
\hline Traits/ Genetic Parameters & $\begin{array}{c}\text { Var } \\
\text { Environmental }\end{array}$ & ECV & $\begin{array}{c}\text { Var } \\
\text { Genotypical }\end{array}$ & GCV & $\begin{array}{c}\text { Var } \\
\text { Phenotypical }\end{array}$ & PCV & $\begin{array}{c}\mathbf{h}^{2} \\
\text { (Broad } \\
\text { Sense) }\end{array}$ & $\begin{array}{c}\text { Genetic } \\
\text { Advancement } \\
5 \%\end{array}$ & $\begin{array}{c}\text { Gen.Adv } \\
\text { as \% of } \\
\text { Mean } 5 \%\end{array}$ \\
\hline Plant Height & 5.02 & 2.58 & 19.74 & 5.11 & 24.76 & 5.73 & 79.70 & 8.17 & 9.41 \\
\hline Days to first flowering & 1.56 & 3.60 & 1.81 & 3.87 & 3.37 & 5.29 & 53.60 & 2.03 & 5.84 \\
\hline Days to $50 \%$ flowering & 0.88 & 2.05 & 2.45 & 3.43 & 3.33 & 3.99 & 73.70 & 2.77 & 6.06 \\
\hline $\begin{array}{l}\text { Number of flower per } \\
\text { cluster }\end{array}$ & 0.87 & 11.83 & 0.27 & 6.53 & 1.14 & 13.52 & 23.40 & 0.51 & 6.51 \\
\hline No. of flower cluster/plant & 1.81 & 12.13 & 1.81 & 12.13 & 3.61 & 17.16 & 50.00 & 1.96 & 17.66 \\
\hline No. of fruit set per cluster & 0.50 & 17.29 & 0.13 & 8.82 & 0.62 & 19.41 & 20.60 & 0.34 & 8.26 \\
\hline Fruit weight & 209.55 & 22.37 & 54.47 & 11.41 & 264.02 & 25.11 & 20.60 & 6.91 & 10.67 \\
\hline No. of fruits per plant & 62.20 & 17.65 & 37.90 & 13.78 & 100.10 & 22.39 & 37.90 & 7.80 & 17.46 \\
\hline No. of locules per fruit & 0.36 & 17.70 & 0.08 & 8.18 & 0.43 & 19.50 & 17.60 & 0.24 & 7.08 \\
\hline Fruit shape index & 0.02 & 14.05 & 0.00 & 5.81 & 0.02 & 15.20 & 14.60 & 0.04 & 4.58 \\
\hline Pericarp thickness & 0.08 & 6.18 & 0.08 & 6.18 & 0.15 & 8.74 & 50.00 & 0.40 & 9.00 \\
\hline Total soluble solid & 0.16 & 11.19 & 0.04 & 5.53 & 0.20 & 12.48 & 19.70 & 0.18 & 5.05 \\
\hline Leaf curl incidence & 6.91 & 9.22 & 40.65 & 22.37 & 47.56 & 24.19 & 85.50 & 12.14 & 42.60 \\
\hline No. of fruit yield per plant & 0.12 & 12.22 & 0.58 & 26.49 & 0.70 & 29.18 & 82.40 & 1.43 & 49.55 \\
\hline
\end{tabular}


Moderate heritability was expressed in days to first flowering (53.60) followed by number of flower cluster per plant (50.00), pericarp thickness (50.00) and no. of fruits per plant (37.90) while fruit shape index (14.6) had exhibited lowest heritability. High heritability values indicate that the characters under study are less influenced by environment in their expression.

The plant breeder, therefore adopt simple selection method on the basis of the phenotype of the characters which ultimately improves the genetic background of these traits. Similar results were also quoted by Nwosu et al., (2014), Meena et al., (2015), Dutta et al., (2018) and Sharmin et al., (2019)

\section{Genetic advance}

The estimates of genetic advance as per cent of mean provide more reliable information regarding the effectiveness of selection in improving the traits. Genetic advance is usually expressed as percent of mean. The range of genetic advance as percent of mean is classified as suggested by (Johnson et al, 1955). Low less than $10 \%$, moderate $10-20 \%$ and high more than 20\%. Genetic advance estimates are depicted in (Table 2).

Among the studied characters the high, moderate and low estimates of genetic advance as percent of mean was recorded. The genetic advance as percentage of mean was highest for number of fruit yield per plant (49.55) and leaf curl incidence (42.60) recorded. However it was exhibited moderate for number of flower cluster per plant (17.66) followed by number of fruits per plant (17.46) and fruit weight (10.67).

Lowest genetic advance as percent of mean recorded for fruit shape index (4.58),total soluble solid (5.05), days to first flowering (5.84) and days to $50 \%$ flowering (6.06).
Similar results were also reported byPatel et al., (2013) and Bhandari et al., (2017) and Dutta et al., (2018).

Therefore, it is concluded that the characters which showed high GCV, PCV and heritability coupled with genetic advance should be considered for direct selection. Here fruit yield per plant and leaf curl incidence the character under study showed high heritability and genetic advance. Thus one should select these characters for direct selection.

\section{References}

Bhandari, H. R., Srivastava, K and Reddy, G. E., (2017).Genetic Variability, Heritability and Genetic Advance for Yield Traits in Tomato (Solanum lycopersicumL.) Int.J.Curr.Microbiol.App.Sci. 6(7): 41314138.

Bugianesi, R., Salucci, M., Leonardi, C., Ferracane, R., Catasta, G., Azzini, E. and Madani, G. (2004). Effect of domestic cooking on human bioavailability of naringenin, chlorogenic acid, lyopene and $\beta$-carotene in cherry tomatoes. European Journal of Nutrition, 43: 360-366.

Burton, G. W. 1952.Quantitative inheritance in grasses. Proc. IV Institute Grassland Congress 1: 155-157.

Burton, G.W. and de Vane, E.W. 1953. Estimating heritability in tall fescue (Festuca arundinaces) from replicated clonal material. Agronomy Journal, 45: 478-481.

Dhaliwal, M. S. S. Singh and D. S. Cheema. (2003). Line $\times$ tester analysis for yield and processing attributes in tomato. Journal of Research 40: 49-53.

Dutta, P., Hazari, S., Karak, C. and Talukdar, S. (2018). Study on genetic variability of different tomato (Solanum lycopersicum. L.) cultivars grown under open field condition. International Journal of Chemical Studies. 6(5): 1706-1709.

Emami, A. and Eivaz, A. R. (2013).Evaluation of Genetic Variations of Tomato Genotypes 
(Solanum lycopersicum L.) with Multivariate Analysis. International Journal of Scientific Research in Environmental Sciences (IJSRES), 1(10): 273-284.

Falconer, D.S.1960.Introduction to quantitative genetics. Longman, New York.

Ghosh, K.P., A.K.M.A. Islam, M. A. K. Mian and M.M. Hossain. (2010). Variability and character association in F2 segregating population of different commercial hybrids of tomato (Solanum lycopersicum L.). Journal of Applied Science and Environmental Management. 14:91-95.

Johnson, H. W. Robinson, H.F. and Comstock, R.E. 1955. Estimates of genetic and environmental variability in soy-beans. Agronomy Journal., 47: 314-318.

Kumar, V. Nandan, R., Srivastava, K., Sharma, S. K., Kumar, R. and Kumar, A. (2013). Genetic parameters and correlation study for yield and quality traits in tomato (Solanum lycopersicum L.). Plant Archives, 13 (1): 463-467.

Maitidevi M, Kathmmandu M (2008). Product chain study tomato. Ministry of Agriculture and Cooperatives, Project Management Unit, Biratnagar, Nepal. 480pp.

Meena, O. P. Bahadur, V., Jagtap, A. B., Saini, P. and Meena, Y. K. (2015). Genetic variability studies of fruit yield and its traits among indeterminate tomato genotypes under open field condition. African Journal of Agricultural Research, 10(32):3170-3177.

Nwosu, D. J., Onakoya, O.A., Okere A.U., Babatunde, A.O. and Popoola, A.F. (2014).Genetic variability and correlations inrainfed tomato (Solanum spps.) accessions in Ibadan, Nigeria. Greener Journal of Agricultural Sciences, 4 (5):211-
219.

Panse, V. G. and Sukhatme, P. V. 1957.Genectics and Quantitative characters in relation to plant breeding. Indian Journal Genetics. 17: 312-328.

Patel, S. A., Kshirsagar, D. B., Attar, A.V., and Bhalekar, M.N. (2013). Study on genetic variability, heritability and genetic advance in tomato. International Journal of Plant Sciences., 8(1): 45-47.

Saleem, M. Y., Iqbal, Q. and Asghar, M. (2013). Genetic variability, heritability, character association and path analysis in $\mathrm{f} 1$ hybrids of tomato. Pakistan Journal of Agricultural Science, 50(4): 649-653:

Sharmin, S., Hannan, A., Tahjib, M., U Arif and Sagor, G H. M. (2019). Genetic association and path coefficient analysis among yield and nutritional traits of tomato (Lycopersicon esculentum L.). Journal of the Bangladesh Agricultural University. 17(2): 187-193.

Shashikanth, Basavaraj, N., Hosamani, R.M., and Patil, B.C. 2010. Genetic variability in tomato (Solanum lycopersicon [Mill]. Wettsd.). Karnataka Journal of Agricultural Sciences., 23(3): 536-537.

Sidhya, P. Koundinya, A.V. and Pandi, M. K. (2014).Genetic variability, heritability and genetic advance in tomato. Environment \& Ecology, 32 (4B): 1737-1740.

Tigchelaar, E.C. (1986). Tomato Breeding. In: M.J. Basset (ed.), Breeding Vegetable Crops. AVI Publishing Co., INC. Westport, Connecticut. pp. 135-171.

Panse VG, Sukhatme (1957). Statistical Method for Agricultural Workers. Indian Council of Agricultural Research Publication, New Delhi.Pp. 1-359 (ed.16).

\section{How to cite this article:}

Shreya Rini Titus and Anita Kerketta and Vijay Bahadur. 2020. Genetic Variability, Heritability and Genetic Advance Studies for Different Characters of Tomato (Solanum lycopersicum L.). Int.J.Curr.Microbiol.App.Sci. 9(12): 1647-1653.

doi: https://doi.org/10.20546/ijcmas.2020.912.196 